\title{
Environmental accounting of a waste management system: outcomes from the emergy analysis
}

\author{
C. Granai, R. M. Pulselli \& R. Ridolfi \\ Department of Chemical and Biosystems Sciences, \\ University of Siena, Italy
}

\begin{abstract}
This paper shows an application of the emergy analysis to the waste management system in the Province of Cagliari, Italy. It aims to consider the importance of waste management within a territorial system by assessing the environmental cost and gain due, directly and indirectly, to waste management processes. It also aims to investigate different steps of this process looking for potential critical points and available strategies for a sustainable waste management in its three phases of waste gathering, waste treatment and waste disposing. A landfill and an incinerator, located within the Province, are studied in order to consider their own environmental efficiency and their role in the waste management process. The emergy method (spelt with an " $\mathrm{m}$ ") is based on the assessment of all the inputs that supply the waste management system and its processes (emergy means energy memory). The expected outcomes are in the form of a comprehensive balance that shows the general behaviour of the system and its parts. Through the emergy synthesis, flows of energy and matter that are used within the process of waste management in the Province of Cagliari, are assessed by a common unit, namely the solar energy joule, and compared to each other. This is performed in order to evaluate how an integrated system including incinerator and dumps works in order to make choices and to achieve a sustainable waste management plan.
\end{abstract}

\section{Introduction}

Global environmental conditions are seriously threatened by man and its growing production and consumption rates, especially in western countries. One aspect of 
the problem is the fact that waste production is greater than the capacity of ecosystems to absorb them. The effects of the accumulation of discharged matter, substances, water, etc., are somewhere evident and the consequences (for instance, the harmful effects on the population) must induce to implement rapid and clear political decisions. For example, disposing this huge amount of wastes in a more efficient (from an economic as well as energetic viewpoint) and less detrimental way would mean managing a "new" resource in compliance to Herman Daly's principles of sustainable development [1].

In a thermodynamic context, waste is defined as an entropic reject. However, from thermodynamic theory we know that the ultimate and degraded form of energy is heat, while any material consistence of tailings is actually a resource that can and must be used in some production process. The aim of a public planner in this field, at local or national level, should consist in selecting the most suitable and efficient procedures and technologies in order to appreciate this "new" resource.

The recycle of matter and the recover of energy are arduous procedures that need careful planning and high initial investment without immediate economic advantages. This kind of projects would provide tangible results in the long run.

This paper presents the application of an environmental accounting system, namely the emergy evaluation, to the waste management system of the Province of Cagliari, with the purpose of evaluating, both quantitatively and qualitatively, some crucial points in order to orient public policy in this field. The main elements of the analysis are the dimension of the system, the energy and matter involved within; the importance of this sector within a territorial sustainability evaluation of the same Province. The analysis enables to highlight the environmental problems related to each phase of the system: gathering, management and disposal of wastes.

\section{Emergy analysis of a waste gathering system}

The emergy analysis (spelt with an " $\mathrm{m}$ ") measures the main resource flows that sustain a territorial system and its population. This accounting method converts different inputs, such as human labor, trucks, fuels, chemicals, to a common unit (the equivalent solar energy) [2,3]; it describes the environmental state of a region with respect to life standard and activities of local population.

Assigning an emergy content to waste means that waste has a certain potential value and does not represent a state of maximum entropy; it is still a resource for the system. Since residues of an ecosystem are the feedstock for another, even Nature does not conceive the concept of waste [4].

However, through the work of Herman Daly, one of the father of Sustainable Development and Ecological Economics, the classic and neoclassic economy, based on the parameters of labor and capital produced by men, have been reloaded by a third parameter, "the natural capital".

This paper presents the emergy analysis of waste as an attempt to introduce the "natural capital" for the evaluation of a waste management system, not only assessing monetary costs and waste quantity. In particular we want: 
- to measure the value of collected materials in terms of solar emergy joule in order to estimate the amount of natural capital lost in the form of waste;

- $\quad$ to promote the idea that waste is still a resource and not only something to dispose;

- to prove the environmental advantage of recovering waste trough an integrated management;

- to propose a hierarchy of possible waste treatments pursuing a high efficiency of the waste management system;

- to suggest new routes for a sustainable waste management to Public Administration.

The emergy content of each material category is given multiplying mass quantities by the transformity.

Table 1: Differentiated and undifferentiated waste production in the Province of Cagliari.

\begin{tabular}{|c|c|c|c|}
\hline \multirow{2}{*}{ Materials } & \multicolumn{3}{|c|}{ PROVINCE OF CAGLIARI } \\
\cline { 2 - 4 } & Differentiated & Undifferentiated & Total \\
\hline YEAR 2001 & $(\mathbf{t})$ & $\mathbf{( t )}$ & $\mathbf{( t )}$ \\
\hline TOTAL & $\mathbf{1 0 , 1 0}$ & $\mathbf{3 8 3 , 0 0}$ & $\mathbf{3 9 3 , 0 0 0}$ \\
\hline ORGANIC & 461 & 149,000 & 150,000 \\
\hline PAPER & 2,78 & 119,000 & 121,000 \\
\hline GLASS & 2,14 & 30,600 & 32,800 \\
\hline PLASTICS & 359 & 38,300 & 38,600 \\
\hline ALUMINIUM & 0.31 & 15,300 & 15,300 \\
\hline BULKIES & 4,32 & - & 4,320 \\
\hline OTHERS & 62.7 & 30,600 & 30,700 \\
\hline
\end{tabular}

Table 2: $\quad$ Emergy flows of differentiated and undifferentiated waste.

\begin{tabular}{|c|c|c|c|c|}
\hline \multirow{2}{*}{ Materials } & Solar & \multicolumn{3}{|c|}{ PROVINCE OF CAGLIARI } \\
& Transformity & Differentiated & Undifferentiated & Total \\
\hline YEAR 2001 & (sej/g) & (sej) & (sej) & (sej) \\
\hline EMERGY & & $\mathbf{1 . 3 4 E + 2 1}$ & $\mathbf{2 . 9 5 E}+\mathbf{1 9}$ & $\mathbf{1 . 3 7 E + 2 1}$ \\
\hline ORGANIC & $3.77 \mathrm{E}+09$ & $5.63 \mathrm{E}+20$ & $1.74 \mathrm{E}+18$ & $5.64 \mathrm{E}+20$ \\
\hline PAPER & $3.15 \mathrm{E}+09$ & $3.74 \mathrm{E}+20$ & $8.75 \mathrm{E}+18$ & $3.82 \mathrm{E}+20$ \\
\hline GLASS & $8.40 \mathrm{E}+08$ & $2.57 \mathrm{E}+19$ & $1.80 \mathrm{E}+18$ & $2.75 \mathrm{E}+19$ \\
\hline PLASTICS & $3.80 \mathrm{E}+08$ & $1.45 \mathrm{E}+19$ & $1.36 \mathrm{E}+17$ & $1.47 \mathrm{E}+19$ \\
\hline ALUMINIUM & $1.60 \mathrm{E}+10$ & $2.45 \mathrm{E}+20$ & $4.94 \mathrm{E}+15$ & $2.45 \mathrm{E}+20$ \\
\hline BULKIES & $3.90 \mathrm{E}+09$ & - & $1.69 \mathrm{E}+19$ & $1.69 \mathrm{E}+19$ \\
\hline OTHERS & $3.77 \mathrm{E}+09$ & $1.15 \mathrm{E}+20$ & $2.36 \mathrm{E}+17$ & $1.16 \mathrm{E}+20$ \\
\hline
\end{tabular}


Mass quantities give the waste system size. The transformity of each material is a specific intensive quantity that depends on its production process. The transformity is therefore the emergy necessary to obtain one unit of a material. Once we have obtained the emergy of each material (multiplying mass quantities by the transformity), we can sum the emergy content of each item; a measure of the total emergy flow corresponding to waste is then achieved (Table 2). In the Province of Cagliari, the emergy flow of waste is $1,37 \times 10^{21}$ sej.

In Figure 1 is shown a graph with the total amounts of emergy flows due to different materials from waste gathering. Organic waste and paper are the most relevant, respectively $41 \%$ and $28 \%$ of the total emergy flow. Aluminium is $18 \%$ due to the high value of the transformity.

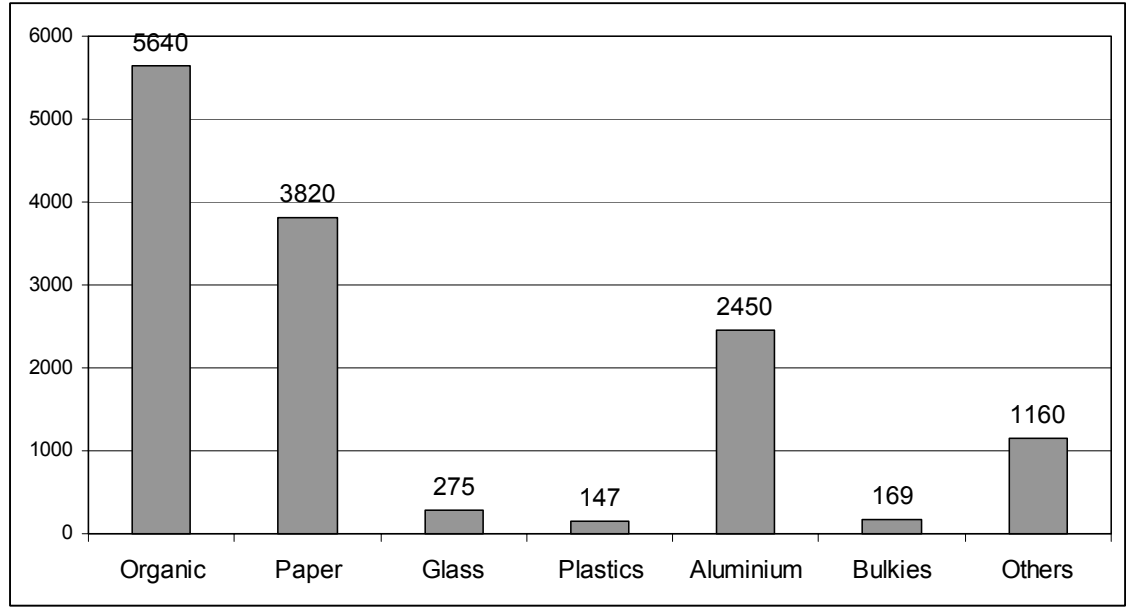

Figure 1: $\quad$ Emergy flows of waste production in the Province of Cagliari.

\section{Emergy analysis of waste treatment and disposing system}

The emergy analysis applied to a waste treatment and disposing system follows a life cycle analysis that provide a schematic description of the process throughout the product's life, from cradle to grave. The waste treatment system has been divided into three different phases: waste gathering (it includes the transportation of wastes from the city's containers to the waste treatment plant), waste treatment (the real process of waste management), and residues treatment (safe deposal of residues) [5]. All inputs, necessary to feed the process, are aggregated per phase and converted in solar emergy units. The aim of this analysis is not to measure the value of waste, in terms of natural capital, but to evaluate the environmental efficiency of a the treatment system in the Cagliari province, and also to evaluate energy recovering processes from waste [6]. Consequently, resources necessary to treat wastes have been accounted, from gathering to the final disposal. From a thermodynamic viewpoint, the best process is the one able to join low emergy investments with an environmental compatible management and with an efficient recovery of materials and energy. 
Table 3: Compared emergy flows of a landfill and an incinerator in the Cagliari province. Emergy investment per ton of treated waste and per MWh of electric production.

\begin{tabular}{|c|c|c|c|c|c|c|}
\hline \multirow{2}{*}{$\begin{array}{c}\text { TYPE } \\
\text { of } \\
\text { TREATMENT }\end{array}$} & Gathering & Treatment & Residues & Total & Investment & Investment \\
\cline { 2 - 7 } & sej & sej & sej & sej & sej/t & sej/MWh \\
\hline LANDFILL (Serdiana) & $1.14 \mathrm{E}+19$ & $1.38 \mathrm{E}+19$ & $3.47 \mathrm{E}+16$ & $\mathbf{2 . 5 2 E + 1 9}$ & $\mathbf{1 . 9 2 E}+\mathbf{1 4}$ & $\mathbf{1 . 5 4 E}+\mathbf{1 0}$ \\
\hline INCINERATOR (casic) & $1.20 \mathrm{E}+19$ & $2.24 \mathrm{E}+19$ & $8.64 \mathrm{E}+18$ & $\mathbf{4 . 3 0 E}+\mathbf{1 9}$ & $\mathbf{2 . 0 7 E}+\mathbf{1 4}$ & $\mathbf{5 . 4 9 E}+\mathbf{0 9}$ \\
\hline TOTAL & $2.34 \mathrm{E}+19$ & $3.62 \mathrm{E}+19$ & $8.67 \mathrm{E}+18$ & $\mathbf{6 . 8 2 E}+\mathbf{1 9}$ & - & - \\
\hline
\end{tabular}

Table 4: $\quad$ Emergy analysis of the landfill (Serdiana).

\begin{tabular}{|c|c|c|c|c|c|}
\hline Item & Units & $\begin{array}{l}\text { Quantity } \\
\text { (units/year) }\end{array}$ & $\begin{array}{c}\text { Solar } \\
\text { Transformity } \\
\text { (sej/units) }\end{array}$ & $\begin{array}{c}\text { Solar } \\
\text { Emergy } \\
\text { (sej/year) }\end{array}$ & $\begin{array}{c}\text { Emergetic } \\
\text { Investment } \\
\text { (sej/t/year) }\end{array}$ \\
\hline \multicolumn{6}{|l|}{ COLLECTION } \\
\hline 1 Collected wastes & $\mathrm{t}$ & $1,31 \mathrm{E}+05$ & & & \\
\hline 2 Collection cost & $€$ & $8,14 \mathrm{E}+06$ & $1,40 \mathrm{E}+12$ & $1,14 E+19$ & $8,68 E+13$ \\
\hline \multicolumn{6}{|l|}{ TREATMENT } \\
\hline 3 Plant cost & $€$ & $3,82 \mathrm{E}+05$ & $1,40 \mathrm{E}+12$ & $5,35 \mathrm{E}+17$ & $4,07 \mathrm{E}+12$ \\
\hline 4 Human work & $\mathrm{J}$ & $1,10 \mathrm{E}+10$ & $7,38 \mathrm{E}+06$ & $8,15 \mathrm{E}+16$ & $6,20 \mathrm{E}+11$ \\
\hline 5 Material & $\mathrm{g}$ & $2,34 \mathrm{E}+10$ & $5,00 \mathrm{E}+08$ & $1,17 \mathrm{E}+19$ & $8,91 \mathrm{E}+13$ \\
\hline 6 Machinery & $\mathrm{g}$ & $1,19 \mathrm{E}+07$ & $6,70 \mathrm{E}+09$ & $7,98 \mathrm{E}+16$ & $6,08 \mathrm{E}+11$ \\
\hline 7 Fuels & $\mathrm{J}$ & $1,14 \mathrm{E}+13$ & $1,21 \mathrm{E}+05$ & $1,38 \mathrm{E}+18$ & $1,05 \mathrm{E}+13$ \\
\hline 8 Electricity & $\mathrm{J}$ & $4,87 \mathrm{E}+05$ & $2,00 \mathrm{E}+05$ & $9,73 \mathrm{E}+10$ & $7,41 \mathrm{E}+05$ \\
\hline \multirow[t]{2}{*}{9 Water } & $\mathrm{g}$ & $1,50 \mathrm{E}+09$ & $2,03 \mathrm{E}+05$ & $3,05 \mathrm{E}+14$ & $2,32 \mathrm{E}+09$ \\
\hline & & & & $1,38 \mathrm{E}+19$ & $1,05 E+14$ \\
\hline \multicolumn{6}{|l|}{ RESIDUAL MATTER TREATMENT } \\
\hline 10 Percolate disposal cost & $€$ & $2,48 \mathrm{E}+04$ & $1,40 \mathrm{E}+12$ & $3,47 E+16$ & $2,64 \mathrm{E}+11$ \\
\hline \multirow[t]{2}{*}{ Electric Energy Production } & & & $4,50 \mathrm{E}+13$ & $(\mathrm{~J} /$ year $)$ & \\
\hline & & & $1,25 \mathrm{E}+04$ & (MWh/ year) & \\
\hline Total Solar Emergy (sum of items from 1 to 10 ) & & & $2,52 \mathrm{E}+19$ & (sej/year) & \\
\hline Phase 1: Collection (item 2) & & & $1,14 \mathrm{E}+19$ & (sej/year) & \\
\hline Phase 2: Treatment (sum of items from 3 to 9) & & & $1,38 \mathrm{E}+19$ & (sej/year) & \\
\hline Phase 3: Treatment of residuals (item 10) & & & $3,47 \mathrm{E}+16$ & (sej/year) & \\
\hline Emergy investment per ton of waste & & & $1,92 \mathrm{E}+14$ & (sej/t/year) & \\
\hline Emergy investment per MWh of energy & & & $1,54 \mathrm{E}+10$ & (sej/t/MWh/year) & \\
\hline
\end{tabular}

\subsection{Managed landfill (Serdiana)}

The plant located in Serdiana municipality is a landfill of first category. It has a total authorized volume of $425,000 \mathrm{~m}^{3}$ with a residual useful capacity of $20,000 \mathrm{~m}^{3}$ in 2001 . The general cost of the plant during the year 2001 is estimated to be 740,000.00 euros. The plant has been constructed in 1997 . Annual average working hours have been estimated in 21,100 per 24 working 
units. Waste buried in the landfill during the year 2001 are 131,000, an average of 250-300 t/g. leachate is disposed in a depuration plant, when it is not recycled in the landfill. The average cost of disposal is $31 € / \mathrm{m}^{3}$. The average biogas production is $1,500 \mathrm{Nm}^{3} / \mathrm{h}$. Electricity production is equal to $12,500,000 \mathrm{kWh} /$ year. $13,000 \mathrm{~m}^{3}$ of inert material are used to bury waste.

From the emergy analysis of Serdiana plant we have obtained the following results:

- The $55 \%$ of all the emergy used is due to the treatment phase.

- The remaining $45 \%$ is mostly relative to waste gathering. The emergy cost of the disposal is almost negligible. This result depends on the low quantity of leachate treated.

- The $46 \%$ of the total emergy flow is due to materials use for the landfill cultivation. The other two meaningful items are plant cost and fuel use, which represents about the $7-8 \%$ of the total emergy.

- The emergy investment per ton of waste treated is $1.92 \times 10^{14} \mathrm{sej} /$ year. The emergy investment per MWh of electricity produced is $1.54 \times 10^{10} \mathrm{sej} / \mathrm{t} / \mathrm{year}$.

Table 5: $\quad$ Emergy analysis of the incinerator (Casic - Macchiareddu).

\begin{tabular}{|c|c|c|c|c|c|}
\hline Item & Units & $\begin{array}{c}\text { Quantity } \\
\text { (units/year) }\end{array}$ & $\begin{array}{c}\text { Solar } \\
\text { Transformity } \\
\text { (sej/units) }\end{array}$ & $\begin{array}{c}\text { Solar } \\
\text { Emergy } \\
\text { (sej/year) }\end{array}$ & $\begin{array}{c}\text { Emergetic } \\
\text { Investment } \\
\text { (sej/t/year) }\end{array}$ \\
\hline \multicolumn{6}{|l|}{ COLLECTION } \\
\hline 1 Collected wastes & $t$ & $1,66 \mathrm{E}+05$ & & & \\
\hline 2 Collection cost & $€$ & $8,57 \mathrm{E}+06$ & $1,40 \mathrm{E}+12$ & $1,20 E+19$ & $7,23 E+13$ \\
\hline \multicolumn{6}{|l|}{ TREATMENT } \\
\hline 3 Human work & $\mathrm{J}$ & $4,13 \mathrm{E}+11$ & $7,38 \mathrm{E}+06$ & $3,04 \mathrm{E}+18$ & $1,83 \mathrm{E}+13$ \\
\hline 4 Electricity & $\mathrm{J}$ & $6,54 \mathrm{E}+13$ & $2,00 \mathrm{E}+05$ & $1,31 \mathrm{E}+19$ & $7,88 \mathrm{E}+13$ \\
\hline 5 Plant cost & $€$ & $3,62 \mathrm{E}+06$ & $1,40 \mathrm{E}+12$ & $5,06 \mathrm{E}+18$ & $3,05 \mathrm{E}+13$ \\
\hline 6 Fuels & $\mathrm{J}$ & $5,11 \mathrm{E}+12$ & $1,21 \mathrm{E}+05$ & $6,18 \mathrm{E}+17$ & $3,72 \mathrm{E}+12$ \\
\hline 7 Water & $\mathrm{g}$ & $3,84 \mathrm{E}+11$ & $2,03 \mathrm{E}+05$ & $7,80 \mathrm{E}+16$ & $4,70 \mathrm{E}+11$ \\
\hline \multirow[t]{2}{*}{8 Chemicals } & $€$ & $3,36 \mathrm{E}+05$ & $1,40 \mathrm{E}+12$ & $4,70 \mathrm{E}+17$ & $2,83 \mathrm{E}+12$ \\
\hline & & & & $2,24 \mathrm{E}+19$ & $1,35 \mathrm{E}+14$ \\
\hline \multicolumn{6}{|l|}{ RESIDUAL MATTER TREATMENT } \\
\hline 9 Slag and ash & $\mathrm{g}$ & $3,47 \mathrm{E}+10$ & $2,49 \mathrm{E}+08$ & $8,64 \mathrm{E}+18$ & $5,20 \mathrm{E}+13$ \\
\hline \multirow[t]{2}{*}{ Electric Energy Production } & $\mathrm{J}$ & $1,36 \mathrm{E}+14$ & & & \\
\hline & $\mathrm{MWh}$ & $3,77 \mathrm{E}+04$ & & & \\
\hline Total Solar Emergy (sum of items from 1 to 8 ) & & $4,30 \mathrm{E}+19$ & (sej/anno) & & \\
\hline Phase 1: Collection (item 2) & & $1,20 \mathrm{E}+19$ & (sej/anno) & & \\
\hline Phase 2: Treatment (sum of items from 3 to 8 ) & & $2,24 \mathrm{E}+19$ & (sej/anno) & & \\
\hline Phase 3: Residual Matter Treatment (Phase 9) & & $8,64 \mathrm{E}+18$ & (sej/anno) & & \\
\hline Emergy investment per ton of waste & & $2,07 \mathrm{E}+14$ & $\operatorname{sej} / \mathrm{t}$ & & \\
\hline Emergy investment per MWh of energy & & $5,49 \mathrm{E}+09$ & $\mathrm{sej} / \mathrm{MWh} / \mathrm{t}$ & & \\
\hline
\end{tabular}

\subsection{Incinerator (Macchiareddu)}

The incinerator located in Macchiareddu is managed by Tecnocasic. It has three burners: two dedicated to MSW and RDF (Refuse Derived Fuel) combustion and one to the incineration of industrial and medical wastes. The cost of the plant that works since 1995 is about 30 million euros. In 2001, the amount of waste incinerated was 136,317 tons, while the amount landfilled is 49,191 tons. 
The electricity production, in 2001, from the three burners is about $37,676,100 \mathrm{kWh}$ excluding a consumption of $18,174,450 \mathrm{kWh}$. The incineration process produces 30,593 tons of drosses and 4,102 tons of ashes.

The emergy analysis of the incinerator shows the following results:

- $52 \%$ of the total emergy is due to the treatment phase.

- Waste gathering represents the $28 \%$ while the final disposal is about the $20 \%$ of the total emergy use.

- The most important items are the electricity and the plant use that represent, respectively, the $31 \%$ and the $12 \%$ of the total emergy use.

- The emergy investment per tons of waste treated is $2.07 \times 10^{14} \mathrm{sej} / \mathrm{year}$.

- The emergy investment per MWh of electricity produced is $5.49 \times 10^{9}$ sej/year.

\section{Conclusion}

The analysis of an integrated waste management system needs a holistic approach to evaluate various steps of the process in a unique balance from waste gathering to waste treatment and disposing. Results highlight the importance of strategic choices addressed to decrease waste production, to increase material recycling and to promote energy production from wastes as a final step, before waste disposing (the ultimate step).

This analysis intends to support choice making process through an environmental accounting method enhancing the idea that the environment is not just an economic externality but a form of capital, namely natural capital.

Results obtained enable to evaluate the environmental weight of waste in terms of solar energy spent or saved, and also the environmental efficiency of two principal processing systems (dumping and incinerator).

The integrated managing system is based on a set of processes for waste management.

Emergy analysis is here applied to evaluate energy and material flows involved in the different processes of waste management.

$\checkmark$ The total emergy flow of waste is $1.37 \times 10^{21}$ sej; this represents a resource from which to obtain the maximum possible energy outcome.

$\checkmark$ Emergy use by the waste management system in various steps (considering a landfill and an incinerator), in the Cagliari Province is $6.83 \times 10^{19}$ sej.

Although the waste management system consumes relevant amounts of resources. This investment, in terms of natural capital, is desirable because of the need to manage waste in a modern society and also because of the opportunity to produce energy, in alternative to fossil fuels.

$\checkmark$ Electric energy production from waste in the Province of Cagliari is equivalent to $1.81 \times 10^{14} \mathrm{~J}$, corresponding to $3.61 \times 10^{19}$ sej.

$\checkmark \quad$ The landfill in Serdiana has an emergy investment of $1.54 \times 10^{10}$ sej per MWh of produced energy; the incinerator in Macchiareddu has a lower value, $5.59 \times 10^{9}$ sej per MWh. 
Dumping needs for a high investment but it extends negative effects due to waste emissions in time. A landfill is like a storage in which waste is stocked generating related problems.

An incinerator, opportunely managed and addressed to produce energy, processes a higher amount of waste decreasing their volume. Energy production from waste could be an environmental efficient process since it saves energy from fossil fuels, and it seems to be a good way to compensate emergy investment.

Anyway, practices for waste production decreasing, waste reusing, material recycling from differentiated waste gathering must be the first solutions to adopt to restrain the waste problem.

\section{References}

[1] Daly, H.E. Toward some operational principles of sustainable development. Ecological Economics, 2, pp. 1-6, 1990.

[2] Odum, H.T. Self organisation, transformity and information. Science, 242, pp. 1132-1139, 1988.

[3] Odum. H.T. Environmental Accounting, Emergy and Environmental Decision Making. Wiley \& Sons, New York, 1996.

[4] Riva, A. and Tiezzi, E. 1997. I rifiuti come risorsa sostenibile, in Gea Speciale (Rimini, Italy): 11:18.

[5] Marchettini, N., R. Ridolfi, E. Tiezzi, 2002. EMergy assessment of an integrated municipal solid waste management. Waste Management and the Environment (C.A. Brebbia, D. Almorza, D. Sale \& V. Popov eds.), WIT Press, Southampton, 575-83, 2002.

[6] Marchettini, N., Ridolfi R., Rustici M.. An environmental analysis for comparing waste management options and strategies. Waste Management, in press, 2006. 